Int. J. Dev. Biol. 56: 341-350 (2012)

doi: $10.1387 /$ ijdb.113406ip

\title{
Regulation of Merkel cell development by Pax6
}

\author{
IDA PARISI and J. MARTIN COLLINSON* \\ School of Medical Sciences, University of Aberdeen, Institute of Medical Sciences, Foresterhill, UK
}

\begin{abstract}
Merkel cells are mechanoreceptors widely distributed in the vertebrate skin. In rodents, Merkel cells within the whisker pads are innervated by free sensory nerve endings derived from the maxillary branch of the trigeminal nerve. This study identified expression of the transcription factor Pax6 in Merkel cells and investigated its role. Immunohistochemistry and Western blot for Pax6 and Merkel cell markers, cytokeratin-8 (K8) and cytokeratin-20 (K20) were performed in wild-type and Pax6 \% fetuses. The subcellular localisation of Pax6 in Merkel cells in vitro was manipulated using hydrogen peroxide. Pax6 was primarily localised within the cytoplasm of the Merkel cells at birth, but postnatally was also detected within the nuclei. In vitro, after 4 days in culture Pax6 protein was completely relocated to the nuclei of fetal-derived Merkel cells, mimicking the in vivo situation, suggesting that Pax6 acts as an active nucleo-cytoplasmic shuttling protein in common with many other homeodomain transcription factors. The subcellular localisation of Pax6 could be modulated in vitro by changing the redox potential of the culture medium for Merkel cells. Differentiation of cultured Pax6 $\%$ Merkel cells was shown to be inhibited. At perinatal stages, it was found that Pax6 is required for maintaining cytokeratin-8 expression, an early Merkel cell marker, whereas cytokeratin-20 was retained by the Pax6 ${ }^{\%}$ mutant cells. Pax6 is expressed in developing Merkel cells as a nucleo-cytoplasmic shuttling protein and its activity is required for normal differentiation, possibly through regulating cell maturation.
\end{abstract}

KEY WORDS: Pax6, Merkel cell, nucleo-cytoplasmic shuttling, oxidative stress

\section{Introduction}

The sensory neurons derived from the maxillary branch of the trigeminal nerve have free endings that innervate skin mechanoreceptors, the Merkel cells (Merkel, 1875). The Merkel cells are mainly located within the basal layer of the epidermis and are found in the hairy skin, including whisker pads (Narisawa et al., 1993, 1994; Halata et al., 2003), and tactile areas within the glabrous skin e.g. foot pads (Moll et al., 1990; Narisawa et al., 1994). Merkel cells contribute to touch perception and are located in the outer root sheath of vibrissal follicles, forming cell-neurite complexes called touch domes (Iggo and Muir, 1969; Halata et al., 2003; Woodbury and Koerber, 2007). A characteristic of the Merkel cells that allows them to be distinguished from keratinocytes is the cytoskeletal structure constituted by the epithelial keratin, cytokeratin-8 (K8 - recognised by the TROMA I monoclonal antibody) and cytokeratin-20 (K20) that have been used as markers for identification of these cell types (Moll et al., 1996; Vielkind et al., 1995).

The mouse atonal homologue 1 (Math1) is the earliest gene identified as being required for the specification and postnatal differentiation of Merkel cells (Ben-Arie et al., 2000; Haeberle et al., 2004; Maricich et al., 2009). Atoh1 null embryos show a decreased number of Merkel cells within the developing skin (Ben-Arie et al., 2000). Atoh1 conditional knock-out (Atoh1 cKO) in the skin resulted in the complete absence of Merkel cells within the touch dome, footpad and whisker pads (Maricich et al., 2009). In Drosophila, atonal controls the development and function of chordotonal stretch receptors (Eberl, 1999; van Staaden and Romer, 1998; Moulins, 1976). The ability of Math1, like ato, to induce ectopic chordotonal organs in Drosophila suggests some level of deep conservation of genetic control of mechanosensory structures (Ben-Arie et al., 2000).

From the earliest stages of embryonic development, the expression of the gene encoding the developmentally regulated transcription factor, Pax6, is detected in the non neural ectoderm

Abbreviations used in this paper: K8, cytokeratin-8; K20, cytokeratin-20; MCC, Merkel cell carcinoma.

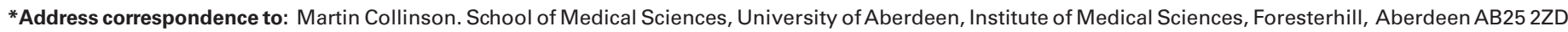
UK. Fax: +44-1224-437465. Tel: +44-1224-437515. e-mail: m.collinson@abdn.ac.uk
}

Supplementary Material (two figures) for this paper is available at: http://dx.doi.org/10.1387/ijdb.113406ip

Accepted: 13 February 2012. Final, author-corrected PDF published online: 15 June 2012.

ISSN: Online 1696-3547, Print 0214-6282

(C) 2012 UBC Press

Printed in Spain 
from where the olfactory and lens placodes will develop (Hogan et al., 1986; Grindley et al., 1995; reviewed in Baker and BronnerFraser, 2001). As a consequence, homozygous null $\left(\mathrm{Pax}^{-/}\right)$mice fail to develop eyes and olfactory epithelia (Hill et al., 1991; Grindley et al., 1995). Pax6 regulates cell-sorting events that ensure the exclusion of Pax6-negative cells from the developing lens and olfactory placode (Collinson et al., 2000). The crucial role of Pax6 in regulating many aspects of eye and nasal development, in embryonic and adult neurogenesis, has been intensively studied (Hill et al., 1991; reviewed in Chalepakis et al., 1993; Simpson and Price 2002; Osumi et al., 2008).

In mice, Pax6 expression starts at embryonic day 8 (E8) in the neural plate. At E10, after neural tube regionalization, Pax6 is expressed in the forebrain, hindbrain and spinal cord (Walther \& Gruss, 1991; Osumi, 2001; Inoue, 2000), where it plays a crucial role in regulating dorsoventral patterning and specification of different neuronal cell types (Ericson et al., 1997; Osumi et al., 1997; Pratt et al., 2000). Pax6 has pivotal roles during central nervous system regionalization, e.g. by regulating boundary formation along the anteroposterior axis (Mastrick et al., 1997; Warren et al., 1997; Matsunaga et al., 2000).

Although some reports suggested a neural crest derivation of the Merkel cells (Grim and Halata, 2000; Szeder et al., 2003), an epidermal lineage origin is nowadays well documented (Moll et al., 1990; Morrison et al., 2009; VanKeymeulen et al., 2009; Woo et al., 2010). Notwithstanding microarray studies on isolated Merkel cells describing expression of other transcription factors involved in neural development, such as Islet1, Brn3b, Sox2 and Mash1 (Haeberle et al., 2004), their specific role in controlling the differentiation and maturation of the Merkel cells is not yet fully understood. The increased interest in studying the genetics and biology of this specialized skin cell type is partly due to the occurrence of a very detrimental and rare tumour, the Merkel cell carcinoma (MCC) (Toker, 1972; Gould et al., 1985).

In this study a previously undescribed domain of Pax6 expression is reported in Merkel cells. Putative roles for Pax6 in regulating Merkel cell development were analysed and characterised. It was observed that Pax6 regulates perinatal development of the Merkel cell, acting as a nucleo-cytoplasmic shuttling protein whose localisation can be modulated by oxidative stress. The requirement for Pax6, a tumour-suppressor, in these cells is relevant to understanding the development and the progression of MCC.

\section{Results}

\section{Pax6 is expressed within Merkel cells in wild-type embryos in vivo}

Pax6-positive cells were observed within the developing whisker follicles from E16.5 onward (Fig. 1). Pax6 was absent from whisker follicles at E14.5 (Fig. 1A), but was detected at E16.5 in a subset of cells (Fig. 1B). Coronal sections at E18.5 demonstrated that these Pax6-positive cells were specifically localised around the papillae (Fig. 1C). As expected, high immuno-reactivity was also detected within the nasal epithelium that was used as positive control for Pax6 expression (Fig. 1D). A role of Pax6 in regulating hair growth was hypothesised and whisker follicle morphology at E16.5 and E18.5 was analysed. At both developmental stages, Pax6-null mutant embryos showed normal structure of the hair follicles (Fig. $1 \mathrm{E}-\mathrm{H}$ ), including, starting from the outmost cell layer, the capsula, dermal sheath, matrix, follicular papillae and the growing hair (Fig. 1E). Normal patterns of hair growth were observed in Pax6-null fetuses at E18.5 (Fig. 1 I,J). The involvement of Pax6 in
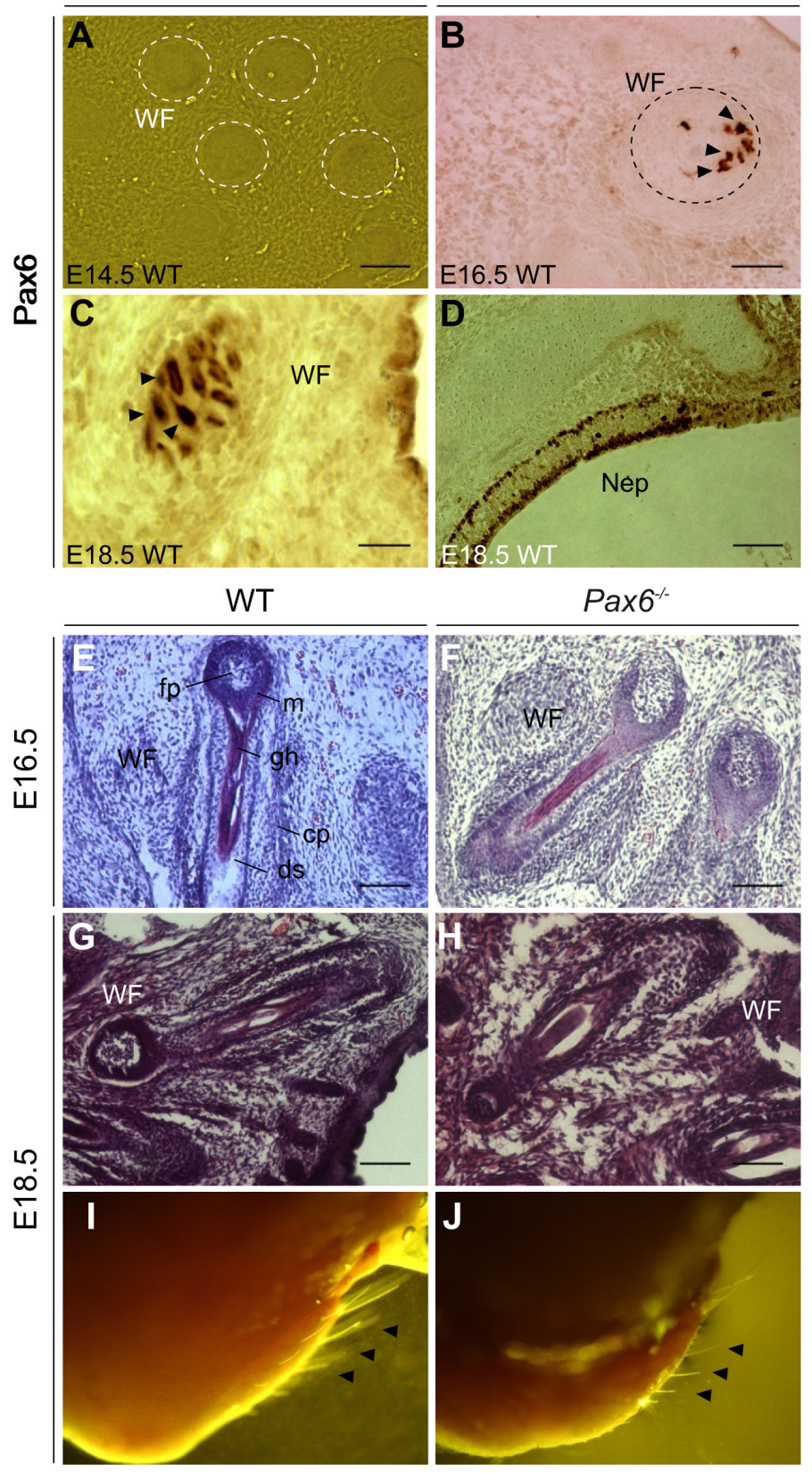

Fig. 1. Pax6 expression in the whisker follicles. (A) Sagittal section through the wild-type whisker pad at E14.5 showing absence of Pax6positive cells. (B) Presence of Pax6-positive cells at E16.5, the whisker follicle is outlined by dashes and the cells are indicated by arrowheads. (C) Pax6-positive cells localised around the whisker papillae at E18.5 (arrowheads). (D) Pax6 expression in the E18.5 nasal epithelium, used as positive control. (E-H) Haematoxylin-eosin staining at E16.5 (E, F) and E18.5 $(G, H)$ in wild-type $(E, G)$ and Pax 6 - mutant embryos $(F, H)$ revealed that hair follicle structure was grossly normal. (I,J) Growing hairs within the E18.5 whisker pad in wild-type (I, arrowheads) and Pax6-null mutant embryos (J, arrowheads). Abbreviations: cp, capsula; ds, dermal sheath; $m$, matrix; fp, follicular papilla; gh, growing hair; Nep, nasal epithelium; WF, whisker follicles. Scale bars: $(A, D, E-H), 90 \mu \mathrm{m}$; (B) $45 \mu \mathrm{m}$; (C) $23 \mu \mathrm{m}$. 
the regulation of the whisker follicle structure and hair growth was therefore potentially excluded.

Merkel cells fully differentiate postnatally but can be identified from E14.5 through the expression of cytokeratin-8 (K8 - detected using the TROMA-I monoclonal antibody) (Moll et al., 1996; Vielkind et al., 1995). At E18.5, Pax6 was found to be expressed in cells which, on the basis of their localisation in the outer root sheath of the follicles, in a pattern similar to K8-positive cells (Fig. $2 \mathrm{~A}, \mathrm{~B})$, were thought to be Merkel cells. As expected, at the same developmental stage, Pax6 was undetectable within the whisker follicles of $\mathrm{Pax}^{-/}$embryos (Fig. 2C). Co-immunolabeling for Pax6 (Fig. 2D) and K8 (Fig. 2E) confirmed the two markers are colocalized within the Merkel cells (Fig. 2F). Surprisingly Pax6 was found to be predominantly localised in the cytoplasm, in contrast to the expected nuclear localisation (Fig. 2F). The expression of cytokeratin-20 (K20), a late marker of the Merkel cells (Tachibana et al., 2000) was also analysed at E18.5. The Pax6 immunolocalisation (Fig. 2G) also overlapped K20 expression (Fig. 2H), confirming the new expression domain within the Merkel cells (Fig. 2I). In order to clarify whether Pax6 is exclusively present within the fetal Merkel cells, its expression was also analysed in hair follicles from postnatal (P4) body skin (Fig. $2 \mathrm{~J}-\mathrm{L}$ ). Pax6 (Fig. 2J) was still co-localised with K20 (Fig. 2K) within the Merkel cells in the outer sheath root of the neonatal hair follicles (Fig. 2L) suggesting it may have a role also in regulating postnatal aspects of Merkel cell development. Interestingly, while Pax6 was mainly localised in the cytoplasm of these cells at E18.5, at P4 the protein was also detected within the nuclei of the Merkel cells (Fig. 2 J',K',L', inset of the boxed regions in $\mathrm{J}, \mathrm{K}$, $\mathrm{L}$ respectively). The results suggested that the subcellular localisation of Pax6 changes from cytoplasm to nucleus at around the time of birth in mice.

Furthermore, the localisation of another molecular marker, the vasoactive

Fig. 2. Pax6 expression overlaps K8/K20 labelling within Merkel cells in vivo. Coronal sections of E18.5 wild-type whisker follicles were stained with anti-Pax6 and anti-K8. (A) K8 labeling of Merkel cells at E18.5. (B) Pax6 expression in cells identified on the basis of their location as Merkel cells. (C) Lack of Pax6 protein in Pax6 $\%$ hair follicle demonstrating specificity of the anti-Pax6 monoclonal antibody. (D-I) At E18.5 Pax6 (D, G) overlapped both $K 8(E)$ and $K 20(H)$ in the cytoplasm of the Merkel cells (representative Merkel cells are indicated by the arrowheads in $F, I)$. (J-L) Postnatally (P4), Pax6 (J) was still retained by the Merkel cells, overlapping K20 expression $(K, L)$. However Pax6 was partially relocated into the nuclei of the cells (L) as shown in panels J', K', L'that represent higher magnifications of the boxed regions respectively in $J, K$ and L. MC, Merkel cells; HS, hair shaft; ORS, outer root sheath. Scale bars $(A, B) 25 \mu \mathrm{m}$; (C) $90 \mu \mathrm{m} ;(D-I) 10 \mu \mathrm{m} ;(J-L) 20 \mu \mathrm{m} ;\left(J^{\prime}-L^{\prime}\right) 05 \mu \mathrm{m}$.

intestinal peptide (VIP), which is known to be expressed in adult Merkel cells, was investigated. VIP was undetectable in perinatal Merkel cells in accordance with previous studies suggesting it is highly expressed only in adults (Hartschuh et al., 1984; Cheng Chew and Leung, 1994). VIP expression was detected only in cells in the dermal matrix or inner root sheath of hair follicles from the body skin of P4 mice (Fig. S1B), not consistent with a Merkel cell localisation, and not overlapping Pax6 (Fig. S1 A,C) thus indicating VIP is not expressed within Merkel cells at P4 in mice.

\section{Pax6 is required for the perinatal development of Merkel cells}

In $\mathrm{Pax6}^{-/}$embryos, K8 and K20 staining of mutant Merkel cells was found at E16.5, without any differences between the wild-type (Fig. $3 \mathrm{~A}-\mathrm{C}$ ) and the mutant cells (Fig. $3 \mathrm{D}-\mathrm{F}$ ), suggesting that Pax6 is likely not required for early specification of this cell type. Interestingly, while K20 expression was retained by both wild-type and $\mathrm{Pax6}^{-1-}$ Merkel cells, K8 staining, in contrast to wild-type, was not detected after E16.5 in Pax6-null mutants ( $n=30$ follicles serially sectioned from 3 different embryos) (Fig. 3 G-L). At earlier stages K8 expression is likely to be under the primary control of other transcription factors such as Math1 (Morrison et al., 2009; Maricich et al., 2009). The results suggested that Pax6 may also be required to maintain Merkel cell differentiation by directly and/or

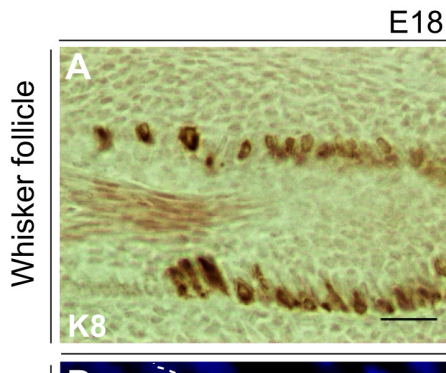

E18.5 WT
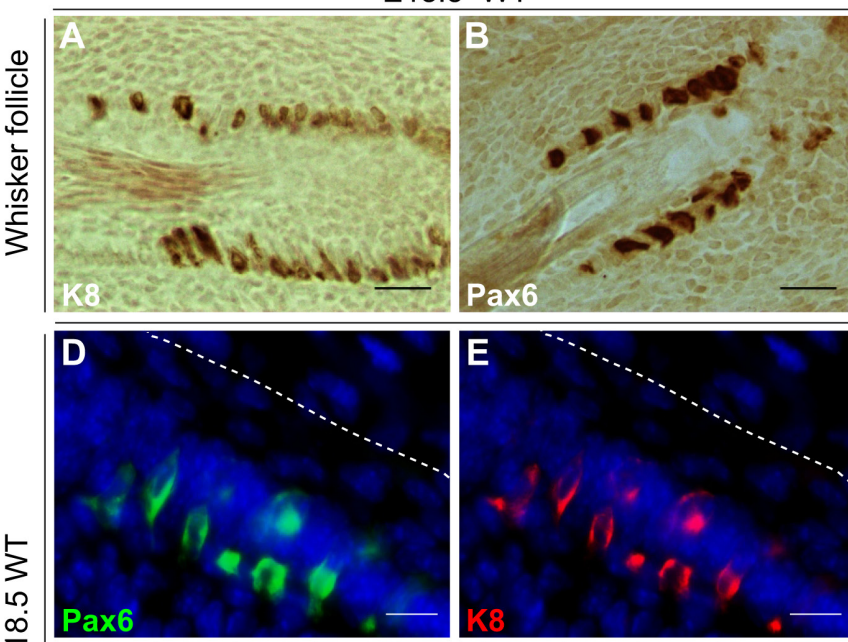

ш
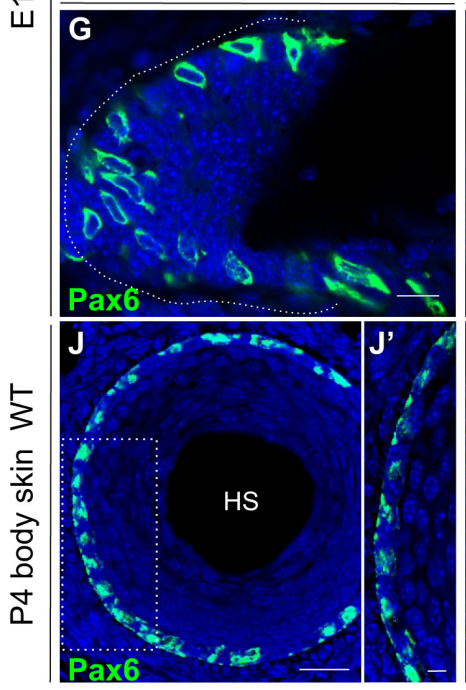
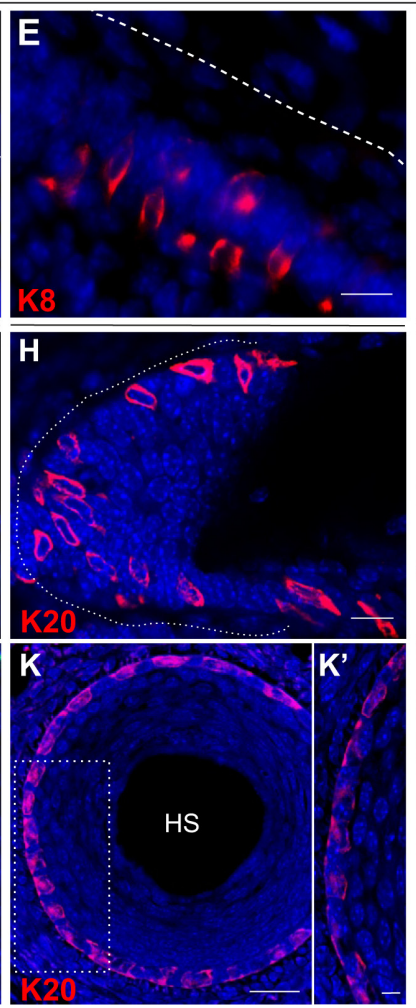

E18.5 Pax6
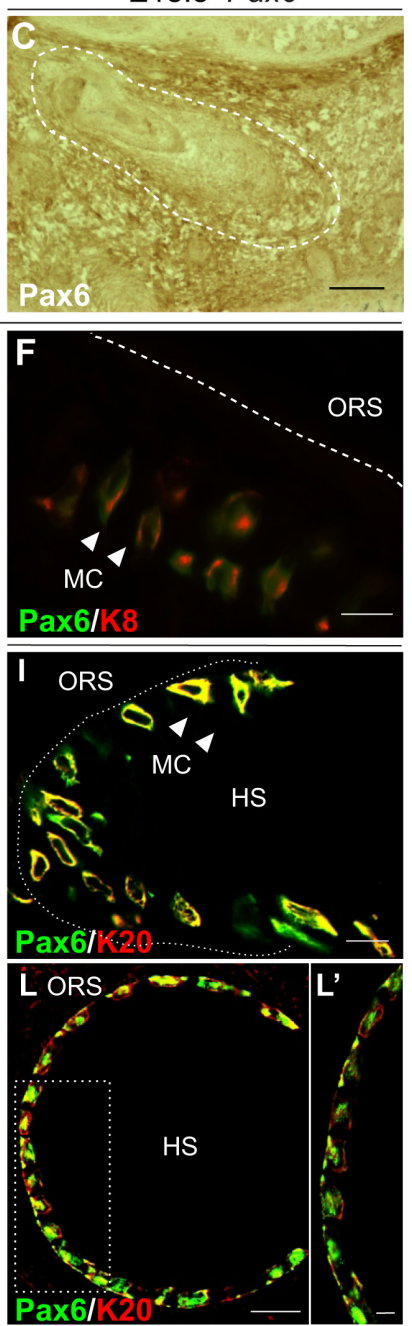


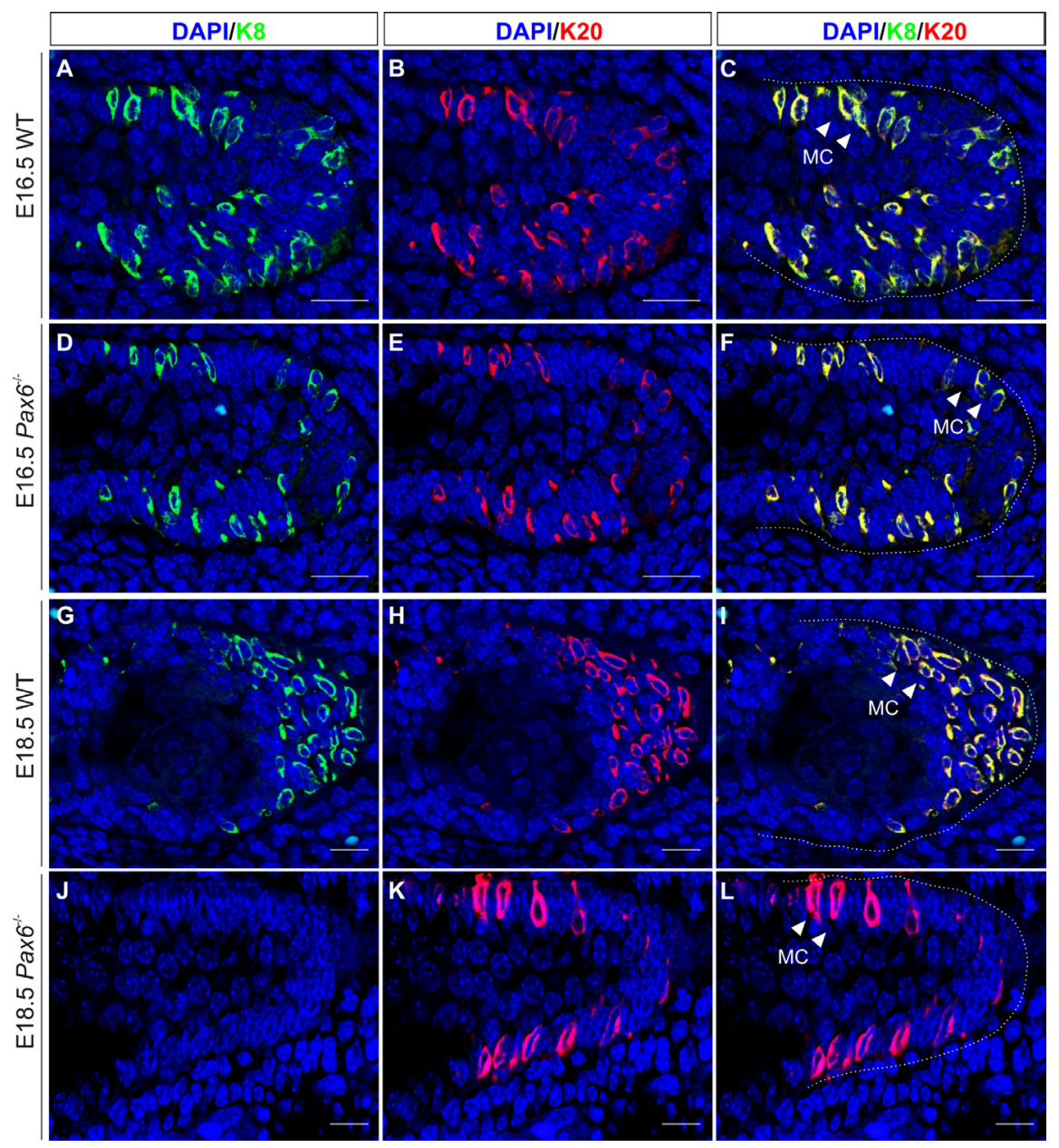

Fig. 3. K8/K20 expression in Pax6 ${ }^{\%}$ Merkel cells. (A-L) K8 (green), K20 (red) and DAPI (nuclear, blue) staining of hair follicles at E16.5 (A-F) and E18.5 (G-L) in wild-type $(A-C, G-I)$ and Pax6 $\%(D-F, J-L)$ fetuses. $K 8$ and K20 are both retained by the Merkel cells of E16.5 Pax6-null mutants (D-F) when compared to the wild-type (A-C). However, at E18.5, while K20 is still present in the Merkel cells from wild-types $(\mathbf{H}, \mathbf{I})$ and Pax6-- mutants $(\mathbf{K}, \mathbf{L})$, K8 expression was never detected in any sections from Pax6- mutants analysed (J-L). The hair follicle is outlined and arrowheads point to selected Merkel cells. MC, Merkel cells; HS, hair shaft; ORS, outer root sheath. Scale bar: $20 \mu \mathrm{m}$.

indirectly regulating exclusively at least one early molecular marker, K8, of this cell type.

\section{Pax6 expression is retained by Merkel cells in vitro and dynamically changes its subcel- Iular localisation}

In order to study in more detail the subcellular distribution of Pax6 protein within Merkel cells, primary cultures of epidermal sheets dissected from the wild-type whisker pads of E18.5 fetuses were set up (modified from Boulais et al., 2009a, 2009b) as described in Materials and Methods. The dissociated cell culture included keratinocytes and in addition, cells were observed that reflected the oval shape and morphology of Merkel cells (Iggo and Muir, 1969; Holbrook and Smith, 1993). It was hypothesised that those showing cytoplasmic protrusions and intimate interactions with the keratinocytes were Merkel

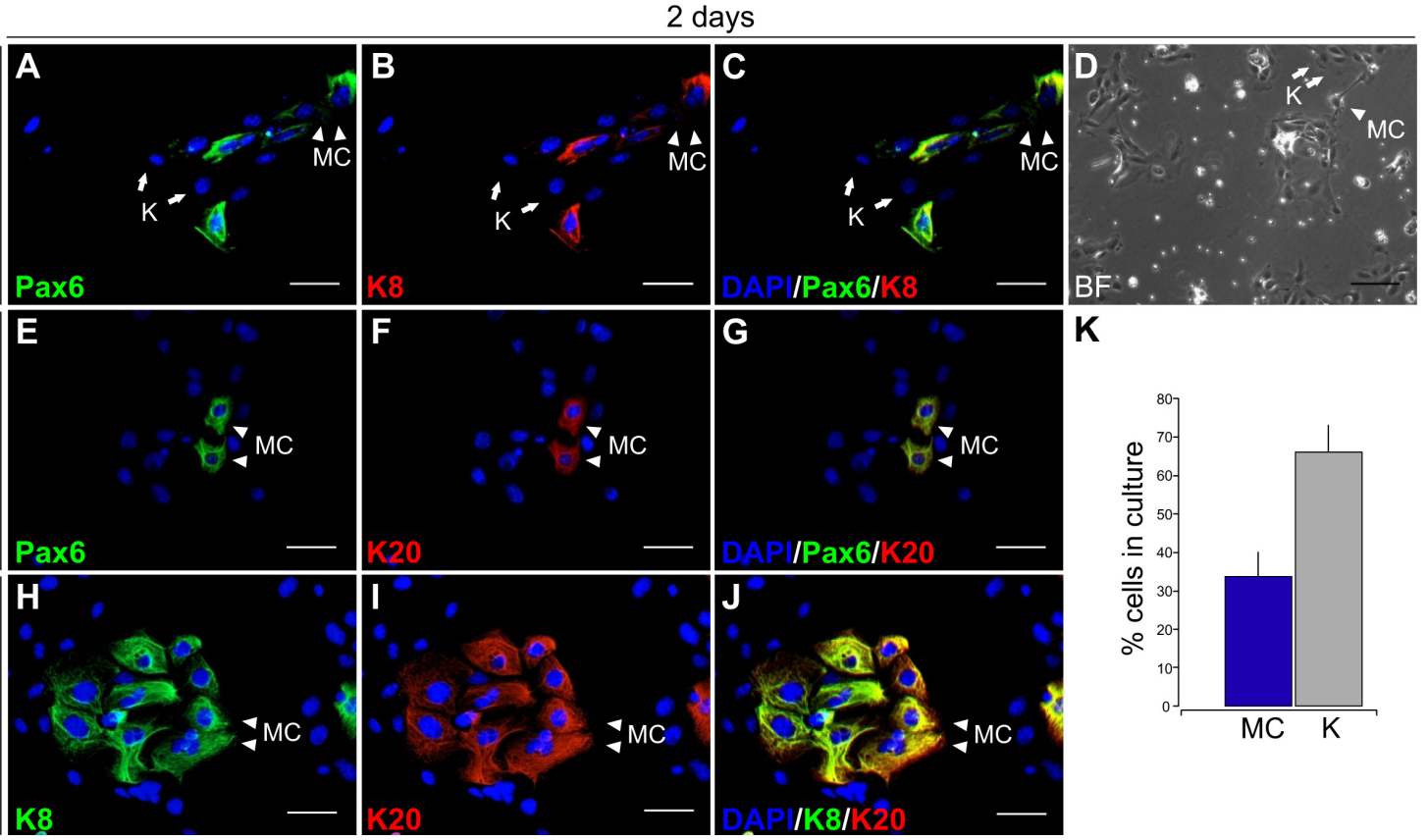

Fig. 4. Embryonic Merkel cells primary culture. (A-K) Immunocytochemistry of mixed embryonic keratinocyte and Merkel cell culture. After two days in culture, cells with protrusions (arrowhead in (D) that contact keratinocytes (arrows) were hypothesised to be the Merkel cells. Co-labelling of Pax6 $(\mathbf{A}, \mathbf{E})$ with $K 8(\mathbf{B})$ and $K 20$ (F) respectively showed it is also localised in the cytoplasm of the Merkel cells in vitro $(\mathbf{C}, \mathbf{G})$. The presumed keratinocytes expressed neither Pax6, K8 nor K20. (H-J) Co-labelling of both $K 8(\mathbf{H})$ and $K 20$ (I) confirmed identification of Merkel cells, with both molecular markers co-expressed (J). Single immunostaining using each antibody on its own produced similar stain-

ing patterns, confirming that data are not the result of cross-reaction. Mean percentage of Merkel cells and keratinocytes in culture is shown in the histogram in (K). K, keratinocytes; MC, Merkel cells. Scale bar: $45 \mu \mathrm{m}$. 
cells as previously described (Moll et al., 1984; Toyoshima et al., 1993) (Fig. 4D). After two days of cell culture, these were found to be labelled by overlapping cytoplasmic localisation of Pax6 and Merkel cell markers K8 (Fig. 4 A-D) and K20 (Fig. 4 E-G). K8 and K20 were colocalised, confirming the identity of these cells as Merkel cells (Fig. $4 \mathrm{H}$-J). These in vitro data recapitulated the results in vivo and confirmed Pax6 expression in Merkel cells. After 2 days in culture the Merkel cells represented $33.8 \% \pm 6 \%$ (expressed as mean value \pm SEM) of the total cells in culture, while the remaining $66.2 \% \pm 6.8 \%$ were keratinocytes ( $n=250$ cells analysed from five replicates) (Fig. 4K).

When the cells were cultured for more than two days a change in the sub-cellular localisation of Pax6 was identified which recapitulated that observed in vivo from perinatal to postnatal stages. From exclusively cytoplasmic localisation at two days in vitro (Fig. 5 A-D), after 3 days some of the cells analysed showed Pax6 in both nuclei and cytoplasm (Fig. 5 E-H). At 4 days Pax6 was completely relocated to the nuclei of the Merkel cells (Fig. 5 I-L) suggesting that dynamic changes in the subcellular localisation of Pax6 occur in vitro as they do in vivo, possibly through an intrinsic mechanism controlling differentiation.

Many lines of evidence suggest that activity of homeodomain transcription factors may be controlled by changes in their subcellular localisation (Prochiantz, 2000; Prochiantz and Joliot, 2003). Nucleocytoplasmic export is a regulated event in eukaryotic cells that occurs through the highly elaborate nuclear pore complexes (NPCs) (Stoffler et al., 1999; Ryan and Wente, 2000).
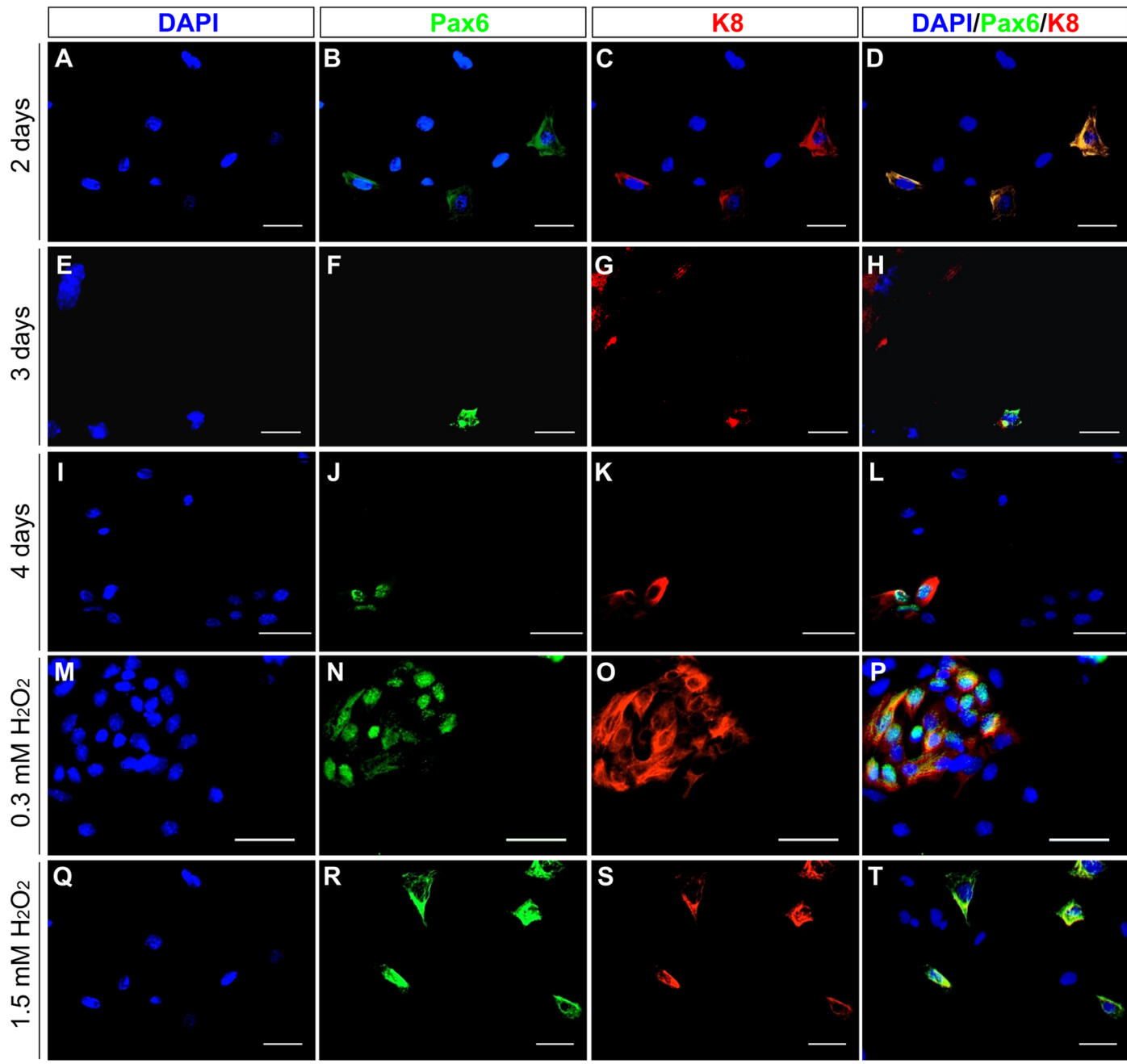

U

V
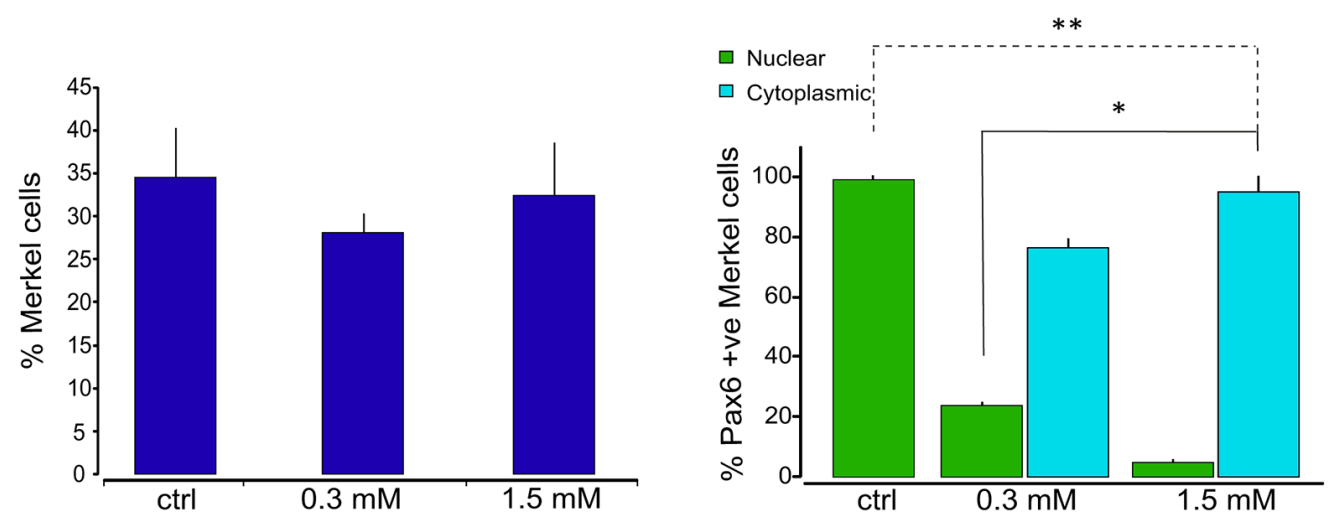

Fig. 5. Subcellular localization of Pax6 is modulated by oxidative stress. Pax 6 and K 8 immunocytochemistry on Merkel cells in vitro. (A-D) After 2 days in culture some cells labelled for both Pax6 and K8, with Pax6 localized in the cytoplasm. After 3 days some of the cells have Pax6 both in the cytoplasm and in the nuclei (E-H). After 4 days in culture Pax6 is completely relocated to the nuclei of the Merkel cells (I-L). (M-P) Upon the addition of 0.3 mM of $\mathrm{H}_{2} \mathrm{O}_{2}$ to 4-day cultures, $76.06 \%$ of the cultured cells relocated Pax6 to the cytoplasm. (Q-T) When $1.5 \mathrm{mM}$ of $\mathrm{H}_{2} \mathrm{O}_{2}$ was added to the primary cell culture nearly all of the cells had Pax6 in the cytoplasm. (U) After addition of $\mathrm{H}_{2} \mathrm{O}_{2}$ the percentage of Merkel cells in culture did not change significantly $(\mathrm{P}=0.67)$. (V) Quantification of percentage of 4-day cultured Merkel cells with nuclear or cytoplasmic localisation of Pax6 under different concentrations of $\mathrm{H}_{2} \mathrm{O}_{2}$. Scale bars (A-H) $23 \mu \mathrm{m}$; (I-T) $45 \mu \mathrm{m}$. 
Active transport requires specific nuclear localisation signals (NLS) and nuclear export signals (NES) within the protein (reviewed in Fabbro and Henderson, 2003; Kohler and Hurt, 2010), amino acid sequences previously described also for Pax6 (LeSaffre et al., 2007), (Fig. S2A, modified from LeSaffre et al., 2007). The online availability of NES prediction server (La Cour et al., 2004; http:// www.cbs.dtu.dk/index.shtml) and protein conformation prediction server (https://www.predictprotein.org) confirmed the potential presence respectively of one NES and two NLSs within the Pax6 protein (LeSaffre et al., 2007), (Fig. S2 A-C).

The in silico analysis was carried out for the three major isoforms of Pax6 protein (Pax6, Pax6(5a), Pax6 $4 \mathrm{PD})$ and resulted in the prediction of 7 residues participating in the formation of a NES in the Pax6 $\triangle P D$ isoform, that lacks the paired domain (Fig. $\mathrm{S} 1 \mathrm{~B})$. The same amino acid sequence is present in all three Pax6 isoforms, but does not yield an equally strong prediction of NES function suggesting the leucine-rich NES sequence may be dynamically masked or unmasked depending on the paired-domain conformation and as consequence of protein folding. Furthermore, western blot analysis carried out on whisker and foot pads from E18.5 embryos, confirmed that Pax6 (with the paired domain) is the major isoform to be expressed within the Merkel cells, as in most Pax6-expressing tissues, and also indicated expression of Pax6 (presumably in Merkel cells) within the glabrous skin, although at a lower level than within the whisker pad (Fig. S2 D).

\section{Oxidative stress modulates Pax6 subcellular localisation}

We previously showed that Pax6 cytoplasmic localisation in the adult corneal epithelium is a consequence of oxidative stress (Ou et al., 2008). In order to analyze if the same mechanism also occurs in Merkel cells, we induced experimental oxidative stress by adding different concentrations of $\mathrm{H}_{2} \mathrm{O}_{2}$ to the cell cultures after 4 days in vitro when Pax6 was completely relocated into the cell nuclei. Interestingly, upon addition of $0.3 \mathrm{mM}$ or $1.5 \mathrm{mM} \mathrm{H}_{2} \mathrm{O}_{2}$ to Merkel cells at 4 days of culture, Pax 6 was found to be excluded from the nucleus (Fig. $5 \mathrm{M}-\mathrm{T}$ ). The percentage of Pax6/K8-positive Merkel cells in culture did not change significantly. As summarised in Fig. 5U, the percentage of Merkel cells in control culture was $32.40 \pm 5.8 \%$ (expressed as mean value \pm SEM); after the addition of $0.3 \mathrm{mM} \mathrm{H}_{2} \mathrm{O}_{2}$ this was $28.4 \pm 2.26 \%$ and after the addition of $1.5 \mathrm{mM} \mathrm{H}_{2} \mathrm{O}_{2}$ was $32.45 \pm 6.2 \%$, suggesting that the induced oxidative stress does not significantly affect the number of Merkel cells in short-term culture (one-way ANOVA: $P=0.67$ ). The differences between the control cells and those treated with the two different concentration of $\mathrm{H}_{2} \mathrm{O}_{2}, 0.3 \mathrm{mM}$ (Fig. $5 \mathrm{M}-\mathrm{P}$ ) and $1.5 \mathrm{mM}$ (Fig. $5 \mathrm{Q}-\mathrm{T}$ ), were statistically significant. Whereas $99.6 \pm 0.4 \%$ of Pax6/K8-positive Merkel cells had nuclear localisation of Pax6 after 4 days in control culture $(n=250$ cells analysed from five replicates), $76.06 \pm 1.3 \%$ of cells showed Pax6 in the cytoplasm upon addition of $0.3 \mathrm{mM} \mathrm{H}_{2} \mathrm{O}_{2}$ ( $\mathrm{n}=250$ cells), (Fig. 5V), (1-way ANOVA: $P<0.0001)$. Moreover, $95.06 \pm 1.5 \%$ of Merkel cells had Pax6 relocated in the cytoplasm after the treatment with $1.5 \mathrm{mM}$ $\mathrm{H}_{2} \mathrm{O}_{2}$ ( $\mathrm{n}=250$ cells), (Fig. 5V) (1-way ANOVA: $\left.P<0.0001\right)$. The difference between cultures with $0.3 \mathrm{mM}$ and $1.5 \mathrm{mM}$ was statistically significant ( $t$-test; $P<0.001)$ suggesting the relocation of Pax6 into the cytoplasm may also be dose-dependent (Fig. 5V).

\section{Pax6 modulates differentiation of Merkel cells in vitro}

As described above, the Merkel cells cultured from the E18.5 whisker pad were positive for both $\mathrm{K} 8$ and K20 (Fig. 6 A-C). In spite of the undetectable expression of $\mathrm{K} 8$ within the $\mathrm{Pax} \mathrm{F}^{-}$Merkel cells found in vivo at $\mathrm{E} 18.5$, both $\mathrm{K} 8$ and $\mathrm{K} 20$ labelling were detected in Pax6 $^{-/}$cells cultured for 4 days (Fig. 6 D-F). This may suggest that lack of Pax6 delays but does not prevent Merkel cell differentiation, or more likely it may indicate a degree of de-differentiation of fetal Merkel cells in culture. Although K8 and K20 labelling were visible in cultured Pax6-null Merkel cells, there were proportionately significantly fewer such cells in culture compared to wild-type. While the K8-K20 double positive Merkel cells from wild-types represented $31.3 \pm 2.1 \%$ (expressed as mean \pm SEM) of the total number of cells, those from Pax6-null mutants were only $21.3 \pm 1.9 \%$, (Fig. 6G) $(t$ test: $P<0.05)$. This finding suggested that, although the Merkel cells from Pax6-null mutants are able in vitro to undergo differentiation, this process may not be as efficient as that occurring in wild-types.
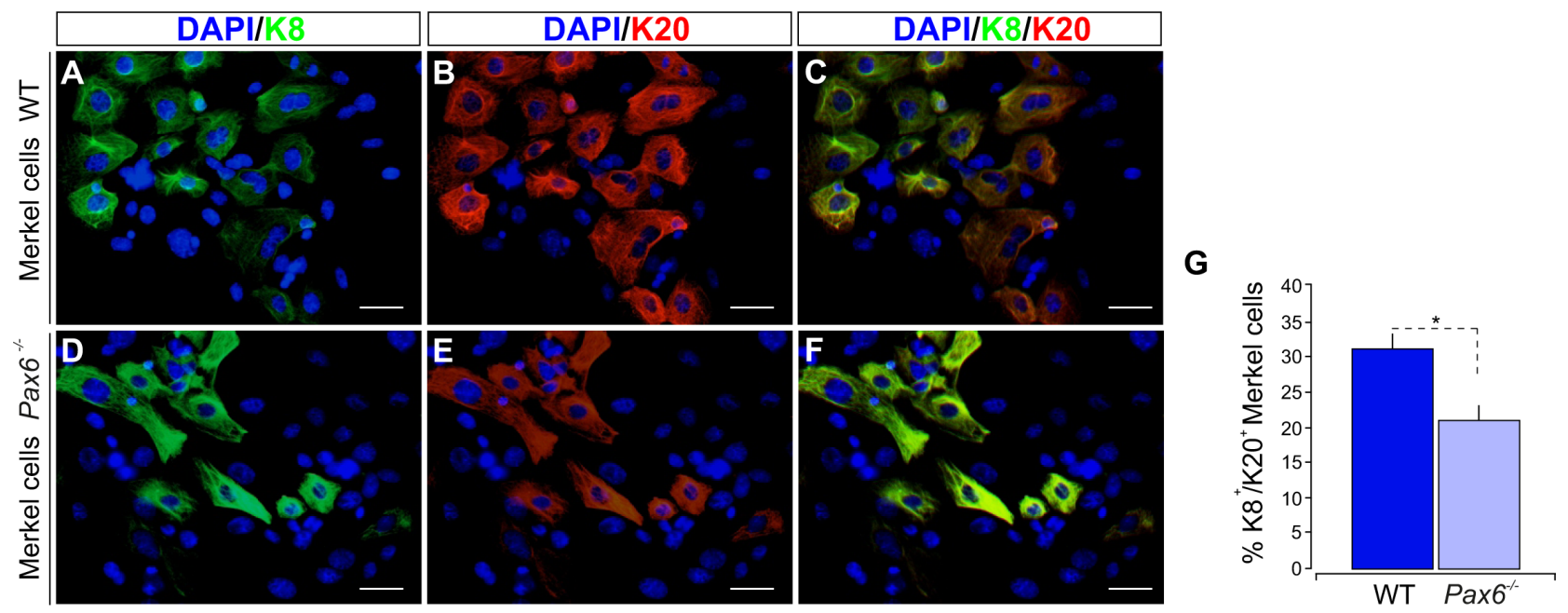

Fig. 6. K8/K20 double-positive Merkel cells are reduced in Pax6 $^{\prime-}$ mutant cultures. (A-F) K8 and K20 expression was retained by both wild-type (AC) and Pax6-null Merkel cells in vitro (D-F). (G) Quantification of the percentage of double-labelled Merkel cells with K8 and K20 showed a significant reduction of the number of Pax6-null Merkel cells. While the Merkel cells from wild-types represented $31.33 \pm 2.08 \%$ (expressed as mean percentage \pm SEM) of the total number of cells, those from Pax6-null mutants were only $21.30 \pm 1.9 \%$ (t-test: $\mathrm{P}<0.05$ ). Scale bar: $45 \mu \mathrm{m}$. 


\section{Discussion}

\section{Pax6 is required for Merkel cell development}

This study showed for the first time that the gene encoding the developmentally regulated transcription factor, Pax6, is expressed in Merkel cells and is required for their normal development. Furthermore the subcellular localisation of Pax 6 protein changes from cytoplasmic to nuclear during differentiation of the cells. Mature K20-positive Merkel cells could nevertheless develop in absence of Pax6 protein. Whereas expression of K8, taken as an earlier marker of Merkel cells, was normal at E16.5 in Pax6 ${ }^{-/}$fetuses, it was absent from E18.5, suggesting that Pax6 perhaps contributes to maintenance of the immature, proliferative differentiation state of Merkel cells. In contrast, $\mathrm{K} 8$ expression was maintained within the $\mathrm{Pax}^{\circ}$ Merkel cells in vitro that have perhaps undergone a degree of dedifferentiation as a result of culture. It is hypothesised that Pax6 may have a role in controlling rates of cell division in Merkel cells and the proportionate underrepresentation of Merkel cells in $\mathrm{Pax}^{\circ}$ culture may be a consequence of cell cycle retardation.

\section{Development of Merkel cells}

Although the epidermal origins of Merkel cells have been extensively reported (Moll et al., 1990; Morrison et al., 2009; VanKeymeulen et al., 2009; Woo et al., 2010), recent studies described the expression of SOX2, a stem cell neural crest transcription factor, in a subpopulation of Merkel cells and melanocytes within the human skin (Laga et al., 2010).

Like Sox2, Pax6 is also a neural transcription factor involved in controlling neural stem cell self-renewal (Sakurai and Osumi, 2007, 2008; Sansom et al., 2009). As stated by Boulais and Misery (2007), the indication of two different developmental origins may not be considered as mutually exclusive. The presence of epidermal neural crest stem cells (eNCSCs) has been proposed, which initially migrate as neural crest precursors and later differentiate only in the epidermis (Boulais and Misery, 2007). A dual ontogenesis for Merkel cells is very intriguing possibility, but the eNCSC population has not yet been experimentally identified.

Given the intense investigation of the roles of Pax6 in embryonic sensory system development, since its identification as the gene responsible for human aniridia and mouse Small eye (Hill et al., 1991; Ton et al., 1991), the discovery of a new expression domain in Merkel cells of hair follicles was surprising.

\section{Pax6 acts as a nucleo-cytoplasmic shuttling transcription factor}

Pax6 is a nuclear transcription factor, however we have shown that, in common with other transcription factors, it undergoes cytoplasmic shuttling (Camarata et al., 2006; Bimber et al., 2007; Ou et al., 2008). Sox10, which regulates many aspects of embryonic development, and Vax2, which participates with Pax6 in retinal development, both dynamically shuttle between the nucleus and the cytoplasm with consequences for their transcriptional activity (Rehberg et al., 2002; Kim and Lemke, 2006). Pax6 interacts with some secreted cytoplasmic proteins such as SPARC (secreted protein acidic and rich in cysteine), a matricellular protein that regulates transport and processing of Pax6 during neuronal primary culture, in the cerebellum and cortex of the mouse brain (Tripathi and Mishra, 2010). Furthermore, there is evidence that Pax6 may be localised in the cytoplasm during synaptic signal- ling (Cooper and Hanson, 2005). Analysis of Pax6 expression in the chick retina showed that Pax6 is localized in the cytoplasm of some cell types (Shin et al., 2003). Pax6 may be considered as an active nucleocytoplasmic protein.

The complete relocation of Pax6 into the nuclei of the Merkel cells in vitro after 4 days in culture indicates that Pax 6 may control some aspects of the postnatal maturation of this cell type. In vivo before birth, only cytoplasmic localisation was observed, but there was significant nuclear relocation of the protein at postnatal stages. In vivo, the predominantly cytoplasmic Pax 6 protein may modulate some aspect of Merkel cell differentiation, for example maintenance of K8 expression. Either there is enough nuclear Pax6 protein in vivo to autonomously control K8 gene expression, or Pax6 has non-genomic roles similar to those described above. The evidence from Pax6 ${ }^{-}$mutants however was that Pax6 is not required for expression of $\mathrm{K} 20$, a marker of mature Merkel cells.

Nucleo-cytoplasmic export is a regulated event characterised by several mechanisms, but the leucine-rich NES has been the most intensively studied (Ossareh-Nazari et al., 2001). It requires the mediation of a specific evolutionarily conserved importin, CRM1 (Haassen et al., 1999), with the participation of a member of the Ras superfamily, Ras-related- nuclear protein (Ran) (Fornerod et al., 1997, Ossareh-Nazari and Dargemont, 1999). CRM1-mediated nuclear export is finely regulated through the masking and unmasking of the NES within the shuttling protein by chemical modifications, such as phosphorylation (Brunet et al., 2002) and formation of disulfide bonds after oxidation (Kuge et al., 2001). Our in silico analysis of the Pax6 protein confirmed the presence of a typical leucine-rich NES sequence that may be dynamically masked or unmasked depending on the paired domain conformation.

\section{Pax6 is required for maintaining cytokeratin-8 expression in vivo}

We also demonstrate that Pax6 is controlling some aspects of Merkel cell development by the direct or indirect regulation of $\mathrm{K} 8$. The data suggest that Pax6 is involved in their perinatal maturation. We could only analyse prenatal Pax6 $^{-/}$mice because the Pax6 mutants die at birth, which limited our observations, as was previously the case with investigation on Atoh-1 null embryos (Ben-Arie et al., 2000). Analysis of $\mathrm{Pax6}^{-/}$cells in a fully developed context by conditional knockout would be a valuable line of future inquiry.

Previous studies in our lab have shown that cytoplasmic Pax6 localisation in the adult corneal epithelium is a consequence of oxidative stress. This was shown to be one of the molecular mechanisms responsible for the corneal abnormalities observed in Pax6 heterozygotes that represent the main model for studying the human congenital eye syndrome, aniridia-related keratopathy (aniridic keratopathy) (Ou et al., 2008). The dose-dependent response of the Merkel cells to addition of $\mathrm{H}_{2} \mathrm{O}_{2}$ was perhaps due to the rise of intracellular calcium and elevated mitogen-activated protein kinase (MAPK) signalling that is activated by $\mathrm{H}_{2} \mathrm{O}_{2}$, events that are commonly associated with inflammation and disease (Nakamura et al., 1997). The findings in the current study extend the observation of dynamic changes in Pax6 subcellular localisation to a physiological developmental process, in addition to the pathological conditions described for the cornea. On the basis of the well-documented role of Pax6 as a tumour suppressor (Salem et al., 2000; Hellwinkel et al., 2008; Ballestar et al., 2003; Zhou et al., 2005; Myers et al., 2006; Nitta et al., 2004; Shyr et al., 2010), it 
is possible to propose a hypothetical model of Pax6 activity within the Merkel cells. Relocation of Pax6 into the Merkel cells nuclei may transcriptionally activate other genes involved in cell cycle arrest.

Merkel cell differentiaton is incompletely understood and Merkel cell carcinoma has a generally poor prognosis. The involvement of a tumour suppressor, Pax6, is therefore of wider interest in a clinical setting. Many tumour-suppressors and oncogenes are active nucleo-cytoplasmic proteins with an NES (reviewed in Fabbro and Henderson, 2003; Kau et al., 2004). Because nuclear transport represents a critical mechanism to regulate transcription factor localisation and function, misregulation of subcellular localisation of tumour-suppressors has been linked to cancer development (Fabbro and Henderson, 2003; Kau et al., 2004; Kohler and Hurt, 2010).

Although the expression of Pax6 in Merkel cells is new to this study, it is intriguing in light of the previously elucidated role of Math1 in these cells. Math1 and Pax6 are both developmentally regulated genes showing many similarities in their expression pattern and genetic regulation together with well documented roles as tumour-suppressors. Furthermore many lines of evidence support mechanistic cross-regulation of these two genes. Binding sites of Pax 6 have been identified within the regulatory sequences of Math1 (Hufnagel et al., 2007). Conversely, a recent study indicated Pax6 to be a direct target of Math1 (Klisch et al., 2011). In addition, studies carried out on eyeless and atonal (Pax6 and Math1 homologues respectively) in Drosophila suggested that both transcription factors share cis-regulatory target regions and thus cooperatively regulate a number of genes (Aerts et al., 2010). Loss of Math1 promotes tumour formation in colorectal cancer (CRC) mouse models and the Math 1 locus is highly mutated and hypermethylated in human tumour samples (Bossuyt et al., 2009), probably through the regulation of Notch signalling pathways (Van Es et al., 2010). The regulation of Pax6 and Math1 in different cell populations offers a very promising field of investigation that may elucidate the link between developmentally regulated events and cancer formation, using Merkel cells as an experimental model.

\section{Materials and Methods}

\section{Mice}

The Pax6 allele used in the present study, Pax6 ${ }^{\mathrm{Sey}-\mathrm{Neu}}$, is an ethylnitrosourea-induced mutation on the CBA/Ca genetic background which acts as a genetic null (Hill et al., 1991). Heterozygous Pax6 ${ }^{+/ \text {Sey-Neu }}\left(\mathrm{Pax6}^{+/}\right)$ parents were crossed under Home Office (UK) licence in order to obtain homozygous, heterozygous and wild-type littermates. Genotypes were confirmed by polymerase chain reaction (PCR) (Quinn et al., 1996).

\section{Immunohistochemical staining}

Embryos were fixed in 4\% paraformaldehyde (PFA), PBS, overnight, and then processed to wax. Seven- $\mu$ m sections were cut. Embryonic heads were sectioned in sagittal and transverse planes. Coronal sections of whisker follicles at E16.5 and E18.5 were stained with haematoxylin and eosin.

Immunostaining was performed as described previously (Collinson et al., 2003). The following primary antibody were used: anti-PAX6 (Developmental Studies Hybridoma Bank, University of lowa, mouse IgG diluted 1:200); anti-cytokeratin 8 endo-A (TROMA-I, Developmental Studies Hybridoma Bank, University of lowa, rat IgG, diluted 1:20); anti-cytokeratin 20 (Abcam, rabbit IgG, diluted 1:200). The following secondary antibodies were used: biotinylated rabbit anti-mouse $\lg G$ (1:300, Sigma), goat anti-rat IgG biotinylated (1:300, Sigma), Alexa488 goat anti-mouse $\lg _{1}(1: 250$, Molecular Probes); Alexa 488 or Alexa 594 rabbit anti-rat IgG (1:250, Molecular Probes) and Alexa 594 goat anti-rabbit (1:250, Molecular Probes).
Sections were inspected and representative images of immunoreactivity were acquired on Nikon Eclipse E400 fluorescence or Zeiss 780LSM confocal laser-scanning microscopes. Images were processed using the ZEN2009 software (Zeiss, Jena, Germany). Multi-panel figures were assembled in CorelDraw X3 (Corel Corp., Ottawa, ON, Canada).

\section{Merkel cell primary culture}

Whisker pads were dissected out from fetal mice (E18.5). The culture method was modified from Boulais et al., (2009a, 2009b). The epidermal sheet was separated from the dermis by enzymatic digestion, incubating the tissue overnight in $5 \mathrm{mg} / \mathrm{ml}$ Dispase II (Sigma, Poole, UK) at $4^{\circ} \mathrm{C}$. Cells were dissociated by digestion with $1 \%$ trypsin-EDTA (Invitrogen, Paisley, UK), assisted by gentle pipetting. Cultured cells (including Merkel cells and keratinocytes) were plated onto plastic tissue-culture dishes (Thermo Fisher Scientific) in Dulbecco's Modified Eagle Medium (DMEM/F12, Invitrogen, Paisley, UK), supplemented with $10 \%$ fetal calf serum (FCS) (Sigma), NGF $20 \mathrm{ng} / \mathrm{ml}$ (Sigma), $20 \mathrm{ng} / \mathrm{ml}$ NT-3 (Sigma) and $25 \mu \mathrm{g} / \mathrm{ml}$ gentamycin (Invitrogen, Paisley, UK) and maintained at $37^{\circ} \mathrm{C} 5 \% \mathrm{CO}_{2}$ for $2-4$ days. Experimental oxidative stress was induced by adding $0.3 \mathrm{mM}$ or $1.5 \mathrm{mM}$ $\mathrm{H}_{2} \mathrm{O}_{2}$ to the cells for two hours. The cells were fixed with $4 \%$ paraformaldehyde, permeabilized with methanol $\left(10\right.$ minutes at $\left.-20^{\circ} \mathrm{C}\right)$ and blocked with $10 \%$ serum from the same animal species as the secondary antibody diluted in $0.3 \%$ BSA, PBS. Immunocytochemistry was performed using the combination of primary and secondary antibodies as described in the previous section.

\section{Statistical methods}

Primary cells stained with anti-K8, anti-K20 and anti-Pax6 antibody from both genotypes were imaged and antigen-positive cells were counted using ImageJ (http://rsbweb.nih.gov/ij/). On each cell dish, at least five fields of view were photographed for a total number of 250 cells from five replicates. The cells stained with DAPI represented the total number of cells. The cells immunoreactive for K8, K20 and Pax6 were then counted and expressed as a percentage of the total number of cells. Percentages of positive cells of different genotypes were compared by $t$-test. A two-tailed unpaired $t$-test was used to compare the subcellular localisation of Pax6 within the Merkel cells before and after the addition of $\mathrm{H}_{2} \mathrm{O}_{2}$. Chi-squared distribution tests were used to determine the statistical significance of differences in the percentage of Merkel cells treated and not treated with $\mathrm{H}_{2} \mathrm{O}_{2}$ ( $\mathrm{n}=250$ cells analysed from five replicates). All reported values are means \pm standard error of the mean (S.E.M.).

\section{Acknowledgments}

IP was supported by the James Mearns Trust PhD studentship at the University of Aberdeen. We wish to thank Dr. Giuseppe Tortoriello for help provided with confocal microscopy and for useful comments on the manuscript. We also wish to thank the anonymous referees for their stimulating comments and suggestions.

\section{References}

AERTS, S., QUAN, X.J., CLAEYS, A., NAVAL SANCHEZ, M., TATE, P., YAN, J. and HASSAN, B.A. (2010).Robust target gene discovery through transcriptome perturbations and genome-wide enhancer predictions in Drosophilauncovers a regulatory basis for sensory specification. PLoS Biol 8: e1000435

BAKER, C.V.H. and BRONNER-FRASER, M. (2001). Vertebrate cranial placodes. I. Embryonic induction. Dev Biol 232: 1-61

BALLESTAR, E., PAZ, M.F., VALLE, L., WEI, S., FRAGA, M.F., ESPADA, J., CIGUDOSA, J.C., HUANG, T.H. and ESTELLER, M. (2003). Methyl-CpG binding proteins identify novel sites of epigenetic inactivation in human cancer. EMBO J 22: 6335-6345.

BEN-ARIE, N., HASSAN, B.A., BERMINGHAM, N.A., MALICKI, D.M., ARMSTRONG, D., MATZUK, M., BELLEN, H.J. and ZOGHBI, H.Y. (2000). Functional conservation of atonal and Math1 in the CNS and PNS. Development 127: 1039-1048. 
BIMBER, B., DETTMAN, R.W. and SIMON, H. (2007). Differential regulation of Tbx5 protein expression and sub-cellular localization during heart development. Dev Biol 302: 230-242.

BOSSUYT, W., KAZANJIAN, A., DE GEEST, N., VAN KELST, S., DE HERTOGH, G., GEBOES, K., BOIVIN, G.P., LUCIANI, J., FUKS, F., CHUAH, M., VANDENDRIESSCHE, T., MARYNEN, P., COOLS, J., SHROYER, N.F. and HASSAN, B.A. (2009). Atonal homolog 1 is a tumor suppressor gene. PLoS Biol 7: e39.

BOULAIS, N. and MISERY, L. (2007). Merkel cells. JAm Acad Dermatol57: 147-165. BOUlais, N., PENNEC, J., LeBONVAllet, N., PEREIRA, U., ROUGIER, N., DORANGE, G., CHESNÉ, C. and MISERY, L. (2009a). Rat Merkel cells are mechanoreceptors and osmoreceptors. PLoS One 4: e6528.

BOULAIS, N., PEREIRA, U., LEBONVALLET, N., GOBIN, E., DORANGE, G., ROUGIER, N., CHESNE, C. and MISERY, L. (2009b). Merkel cells as putative regulatory cells in skin disorders: An in vitro study. PLoS One 4: e6528.

BRUNET, A., KANAI, F., STEHN, J., XU, J., SARBASSOVA, D., FRANGIONI, J.V., DALAL, S.N., DECAPRIO, J.A., GREENBERG, M.E. and YAFFE, M.B. (2002). 14-3-3 transits to the nucleus and participates in dynamic nucleocytoplasmic transport. $J$ Cell Biol 156: 817-828.

CAMARATA, T., BIMBER, B., KULISZ, A., CHEW, T., YEUNG, J. and SIMON, H. (2006). LMP4 regulates Tbx5 protein subcellular localization and activity. J Cell Biol 174: 339-348.

CHALEPAKIS, G., STOYKOVA, A., WIJNHOLDS, J., TREMBLAY, P. and GRUSS, P. (1993). Pax: Gene regulators in the developing nervous system. J Neurobiol 24: 1367-1384.

CHENG CHEW, S.B. and LEUNG, P.Y. (1994). Ultrastructural study of the Merkel cell and its expression of metenkephalin immunoreactivityduring fetal and postnatal development in mice. J Anat 185: 511-520.

COLLINSON, J.M., HILL, R.E. and WEST, J.D. (2000). Different roles for Pax6 in the optic vesicle and facial epithelium mediate early morphogenesis of the murine eye. Development 127: 945-956.

COLLINSON, J.M., QUINN, J.C., HILL, R.E. and WEST, J.D. (2003). The roles of Pax6 in the cornea, retina, and olfactory epithelium of the developing mouse embryo. Dev Biol 255: 303-312.

COOPER, S.T. and HANSON, I.M. (2005). A screen for proteins that interact with PAX6: C- terminal mutations disrupt interaction with HOMER3, DNCL I and TRIM II. BMC Genet 6: 43-52.

EBERL, D.F. (1999). Feeling the vibes: Chordotonal mechanisms in insect hearing. Curr Opin Neurobiol 9: 389-393

ERICSON, J., RASHBASS, P., SCHEDL, A., BRENNER-MORTON, S., KAWAKAMI, A., VAN HEYNINGEN, V., JESSELL, T.M. and BRISCOE, J. (1997). Pax6 controls progenitor cell identity and neuronal fate in response to graded Shh signaling. Cell 90: 169-180.

FABBRO, M. and HENDERSON, B.R. (2003). Regulation of tumor suppressors by nuclear-cytoplasmic shuttling. Exp Cell Res 282: 59-69.

FORNEROD, M., OHNO, M., YOSHIDA, M. and MATTAJ, I.W. (1997). CRM1 is an export receptor for leucine-rich nuclear export signals. Cell 90: 1051-1060.

GOULD, V.E., MOLL, R., MOLL, I., LEE, I. and FRANKE, W.W. (1985). Neuroendocrine (Merkel) cells of the skin: hyperplasias, dysplasias, and neoplasms. Lab Invest 52: 334-353.

GRIM, M. and HALATA, Z. (2000). Developmental origin of avian Merkel cells. Anat Embryol 202: 401-410.

GRINDLEY, J.C., DAVIDSON, D.R. and HILL, R.E. (1995). The role of Pax-6 in eye and nasal development. Development 121: 1433-1442.

HAASEN, D., KÖHLER, C., NEUHAUS, G. and MERKLE, T. (1999). Nuclear export of proteins in plants: AtXPO1 is the export receptor for leucine-rich nuclear export signals in Arabidopsis thaliana. Plant J 20: 695-705.

HAEBERLE, H., FUJIWARA, M., CHUANG, J., MEDINA, M.M., PANDITRAO, M.V., BECHSTEDT, S., HOWARD, J. and LUMPKIN, E.A. (2004). Molecular profiling reveals synaptic release machinery in Merkel cells. Proc Natl Acad Sci USA 101: 14503-14508

HALATA, Z., GRIM, M. and BAUMAN, K. (2003). Friedrich Sigmund Merkel and his "Merkel cell", morphology, development and physiology: review and new results. Anat $\operatorname{Rec}(A)$ 271: 225-239.

HARTSCHUH, W., REINECKE, M., WEIHE, E. and YANAIHARA, N. (1984). VIPimmunoreactivity inthe skin of various mammals: immunohistochemical, ra- dioimmunologicaland experimental evidence for a dual localization in cutaneous nerves and merkel cells. Peptides 5:239-245.

HELLWINKEL, O.J., KEDIA, M., ISBARN, H., BUDÄUS, L. and FRIEDRICH, M.G (2008). Methylation of the TPEF- and PAX6-promoters is increased in early bladder cancer and in normal mucosa adjacent to pTa tumours. Brit J Urol Int 101: 753-757.

HILL, R.E., FAVOR, J., HOGAN, B.L.M., TON, C.C.T., SAUNDERS, G.F., HANSON, I.M., PROSSER, J., JORDAN, T., HASTIE, N.D. and VAN HEYNINGEN, V. (1991) Mouse small eye results from mutations in a paired-like homeobox-containing gene. Nature 354: 522-525.

HOGAN, B.L.M., HORSBURGH, G. and COHEN, J. (1986). Small eyes (Sey): A homozygous lethal mutation on chromosome 2 which affects the differentiation of both lens and nasal placodes in the mouse. J Embryol Exp Morph 97: 95-110.

HOLBROOK, K.A. and SMITH, L. (1993). Morphology of connective tissue: structure of the skin and tendon. In: ROYCE, P.M. and STEINMANN, B., Connective Tissue and Heritable Disorders Wiley-Less, New York, pp. 51-71.

HUFNAGEL, R.B., RIESENBERG, A.N., SAUL, S.M. and BROWN, N.L. (2007) Conserved regulation of Math5 and Math1 revealed by Math5-GFP transgenes. Mol Cell Neurosci 36: 435-448.

IGGO, A. and MUIR, A.R. (1969). The structure and function of a slowly adapting touch corpuscle in hairy skin. J Physiol 200: 763-796.

INOUE, T., NAKAMURA, S. and OSUMI, N. (2000). Fate mapping of the mouse prosencephalic neural plate. Dev Biol 219: 373-383.

KAU, T.R., WAY, J.C. and SILVER, P.A. (2004). Nuclear transport and cancer: from mechanism to intervention. Nat Rev Cancer 4: 106-117.

KIM, J.W.and LEMKE, G. (2006). Hedgehog-regulated localization of Vax2 controls eye development. Gene Dev 20: 2833-2847.

KLISCH, T.J., XI, Y., FLORA, A., WANG, L., LI, W. and ZOGHBI, H.Y. (2011). In vivo Atoh1 targetome reveals howa proneural transcription factor regulates cerebellar development. Proc Natl Acad Sci USA 108: 3288-3293.

KÖHLER, A. and HURT, E. (2010). Gene regulation by nucleoporins and links to cancer. $\mathrm{Mol}$ Cell 38: 6-15.

KUGE, S., ARITA, M., MURAYAMA, A., MAETA, K., IZAWA, S., INOUE, Y. and NOMOTO, A. (2001). Regulation of the yeast Yap1p nuclear export signal is mediated by redox signal-induced reversible disulfide bond formation. $\mathrm{Mol} \mathrm{Cell} \mathrm{Biol}$ 18: 6139-6150.

LACOUR, T., KIEMER, L., MØLGAARD, A., GUPTA, R., SKRIVER, K. and BRUNAK, S. (2004). Analysis and prediction of leucine-rich nuclear export signals. Prot Eng Des Sel 17: 527-536

LAGA, A. C., LAI, C. Y., ZHAN, Q., HUANG, J.S., VELAZQUEZ, E.F., YANG, Q., HSU, M.Y. AND MURPHY, G.F. (2010). Expression of the Embryonic Stem Cell Transcription Factor SOX2 in Human Skin. Relevance to Melanocyte and Merkel Cell Biology. Am J Pathol 176: 903-913.

LESAFFRE, B., P, A., PROCHIANTZ, A. and VOLOVITCH, M. (2007). Direct noncell autonomous Pax6 activity regulates eye development inthe zebrafish. Neural Dev 17: 2-12.

MARICICH, S.M., WELLNITZ, S.A., NELSON, A.M., LESNIAK, D.R., GERLING, G.J., LUMPKIN, E.A. and ZOGHBI, H.Y. (2009). Merkel cells are essential for light-touch responses. Science 324: 1580-1582.

MASTICK, G.S., DAVIS, N.M., ANDREWS, G.L. and EASTER JR., S.S. (1997). Pax6 functions in boundary formation and axon guidance in the embryonic mouse forebrain. Development 124: 1985-1997.

MATSUNAGA,E., ARAKI, I. AND NAKAMURA, H. (2000). Pax6 defines the di-mesencephalic boundary by repressing En1 and Pax2. Development 127: 2357-2365.

MAYES, D.A., HU, Y., TENG, Y., SIEGEL, E., WU, X., PANDA, K., TAN, F., YUNG W.K.A. and ZHOU, Y. (2006). PAX6 suppresses the invasiveness of glioblastoma cells and the expression of the matrix metalloproteinase-2 gene. Cancer Res 66: $9809-9817$

MERKEL, F. (1875). Tastzellen and Tastkoerperchen bei den Hausthieren und beim Menschen. Arch Mikrosc Anat 11: 636 - 652.

MOLL, R., MOLL, I. and FRANKE, W.W. (1984). Identification of Merkel cells in human skin by specific cytokeratin antibodies: Changes of cell density and distribution in fetal and adult plantar epidermis. Differentiation 28: 136-154.

MOLL, I., LANE, A.T., FRANKE, W.W. and MOLL, R. (1990). Intraepidermal formation of Merkel cells in xenografts of human fetal skin. J Invest Dermatol 94: 359-364. 
MOLL, I., ZIEGER, W. and SCHMELZ, M. (1996). Proliferative Merkel cells were not detected in human skin. Arch Dermatol Res 288: 184-187.

MORRISON, K.M., MIESEGAES, G.R., LUMPKIN, E.A. and MARICICH, S.M. (2009). Mammalian Merkel cells are descended from the epidermal lineage. Dev Biol 336: 76-83.

MOULINS, M. (1976). Ultrastructure of chordotonal organs. Structure and Function of Proprioceptors in the Invertebrates (ed. P.J. Mill), pp. 387-426. London: Chapman and Hall.

NAKAMURA, H., NAKAMURA, K. and YODOI, J. (1997). Redox regulation of cellular activation. Annu Rev Immunol 15: 351-369.

NARISAWA, Y., HASHIMOTO, K. and KOHDA, H. (1994). Immunohistochemical demonstration of the expression of neurofilament proteins in Merkel cells. Acta Derm-Venereol 74: 441-443.

NARISAWA, Y., HASHIMOTO, K., NAKAMURA, Y. and KOHDA, H. (1993). A high concentration of Merkel cells in the bulge prior to the attachment of the arrector pili muscle and the formation of the perifollicular nerve plexus in human fetal skin. Arch Dermatol Res 285: 261-268.

NITTA, Y., YOSHIDA, K., SATOH, K., SENBA, K., NAKAGATA, N., PETERS, J. and CATTANACH, B.M. (2004). Spontaneous and radiation-induced leukemogenesis of the mouse small eye mutant, Pax6 (Sey3H). J Rad Res (Tokyo). 45: 245-251.

OSSAREH-NAZARI, B., GWIZDEK, C. and DARGEMONT, C. (2001). Protein export from the nucleus. Traffic 2: 684-689.

OSSAREH-NAZARI, B. and DARGEMONT, C. (1999). Domains of Crm1 involved in the formation of the Crm1, RanGTP, and leucine-rich nuclear export sequences trimeric complex. Exp Cell Res 252: 236-241.

OSUMI, N., HIROTA, A., OHUCHI, H., NAKAFUKU, M., IIMURA, T., KURATANI, S., FUJIWARA, M., NOJI, S. and ETO, K. (1997). Pax-6 is involved in the specification of hindbrain motor neuron subtype. Development 124: 2961-2972.

OSUMI, N. (2001). The role of Pax6 in brain patterning. Tohoku J Exp Med 193: 163-174.

OSUMI, N., SHINOHARA, H., NUMAYAMA-TSURUTA, K. and MAEKAWA, M. (2008). Concise review: Pax6 transcription factor contributes to both embryonic and adult neurogenesis as a multifunctional regulator. Stem Cells 26: 1663-1672.

OU, J., WALCZYSKO, P., KUCEROVA, R., RAJNICEK, A.M., MCCAIG, C.D., ZHAO, M. and COLLINSON, J.M. (2008). Chronic wound state exacerbated by oxidative stress in $\mathrm{Pax}^{+/}$aniridia-related keratopathy. J Pathol 215: 421-430.

PRATT, T., VITALIS, T., WARREN, N., EDGAR, J.M., MASON, J.O. and PRICE, D.J. (2000). A role for Pax6 in the normal development of dorsal thalamus and its cortical connections. Development 127: 5167-5178.

PROCHIANTZ, A. and JOLIOT, A. (2003). Can transcription factors function as cellcell signalling molecules Nat Rev Mol Cell Biol 4: 814-819.

PROCHIANTZ, A. (2000). Messenger proteins: homeoproteins, TAT and others. Curr Opin Cell Biol 12: 400-406.

QUINN, J.C., WEST, J.D. and HILL, R.E. (1996). Multiple functions for Pax6 in mouse eye and nasal development. Genes Dev 10: 435-446.

REHBERG, S., LISCHKA, P., GLASER, G., STAMMINGER, T., WEGNER, M. and ROSORIUS, O. (2002). Sox 10 is an active nucleocytoplasmic shuttle protein, and shuttling is crucial for Sox10-mediated transactivation. Mol Cell Biol22: 5826-5834.

RYAN,K.J.and WENTE,S.R.(2000).The nuclear pore complex:a protein machine bridging the nucleus and cytoplasm. Curr Opin Cell Biol 12: 361-371.

SAKURAI, K. and OSUMI A. N. (2007). The roles of Pax6 in postnatal hippocampal neurogenesis in the mouse. In: ESASHI, M., ISHI, K., OHUCHI, N et al., eds. Future Medical Engineering Based on Biotechnology: Proceedings of the Final Symposium of the Tohoku University $21^{\text {st }}$ Century Center of Excellence Program. London: Imperial College Press, pp. 183-188.

SAKURAI, K. and OSUMI, A. N. (2008). The neurogenesis-controlling factor, Pax6, inhibits proliferation and promotes maturation in murine astrocytes. $J$ Neurosci 28: 4604-4612.

SALEM, C.E., MARKL, I.D.C., BENDER, C.M., GONZALES, F.A., JONES, P.A. and LIANG, G. (2000). PAX6 methylation and ectopic expression in human tumor cells. Int J Cancer 87: 179-185.
SANSOM, S.N., GRIFFITHS, D.S., FAEDO, A., KLEINJAN, D.J., RUAN, Y., SMITH J., VAN HEYNINGEN, V., RUBENSTEIN, J.L. and LIVESEY, F.J. (2009). The level of the transcription factor Pax6 is essential for controlling the balance between neural stem cell self-renewal and neurogenesis. PLoS Genet 5: e1000511

SHIN, D.H., KWON, B.S., CHANG, Y.P., BAE, S., KIM, J. and KIM, J.W. (2003). Ultramicroscopical immunolocalization of PAX6 in the adult chicken retina. Acta Histochem 105: 267-272.

SHYR, C., TSAI, M., YEH, S., KANG, H., CHANG, Y., WONG, P., HUANG, C., HUANG, K.-. and CHANG, C. (2010). Tumor suppressor PAX6 functions as androgen receptor co-repressor to inhibit prostate cancer growth. Prostate 70: 190-199.

SIMPSON, I.T. and PRICE, D.J. (2002). Pax6; a pleiotropic player in development. BioEssays 24: 1041-1051.

STOFFLER, D., FAHRENKROG, B. and AEBI, U. (1999). The nuclear pore complex: from molecular architecture to functional dynamics. Curr Opin Cell Bio/11:391-401.

SZEDER, V., GRIM, M., HALATA, Z. and SIEBER-BLUM, M. (2003). Neural crest origin of mammalian Merkel cells. Dev Biol 253: 258-263.

TACHIBANA, T., FUJIWARA, N. and NAWA, T. (2000). Postnatal differentiation of Merkel cells in the rat palatine mucosa, with special reference to the timing of peripheral nerve development and the potency of cell mitosis. Anat Embryol (Berl) 202:359-367.

TOKER, C. (1972). Trabecular carcinoma of the skin. Arch Dermatol 105: 107-110.

TON, C.C.T., HIRVONEN, H., MIWA, H., WEIL, M.M., MONAGHAN, P., JORDAN, T., VAN HEYNINGEN, V., HASTIE, N.D., MEIJERS-HEIJBOER, H., DRECHSLER, M., ROYER-POKORA, B., COLLINS, F., SWAROOP, A., STRONG, L.C. and SAUNDERS, G.F. (1991). Positional cloning and characterization of a paired box- and homeobox-Containing gene from the aniridia region. Cell67: 1059-1074.

TOYOSHIMA, K., SETA, Y., NAKASHIMA, T. and SHIMAMURA, A. (1993). Occurrence of melanosome-containing Merkel cells in mammalian oral mucosa. Acta Anat (Basel) 147: 145-148.

TRIPATHI, R. and MISHRA, R. (2010). Interaction of Pax6 with SPARC and p53 in brain of mice indicates Smad3 dependent auto-regulation. J Mol Neurosci 41:397-403.

VAN ES, J.H., DE GEEST, N., VAN DE BORN, M., CLEVERS, H. and HASSAN, B.A. (2010). Intestinal stem cells lacking the Math1 tumour suppressor are refractory to Notch inhibitors. Nat Commun 17: 1-18

VAN KEYMEULEN, A., MASCRE, G., YOUSEFF, K.K., HAREL, I., MICHAUX, C., DE GEEST, N., SZPALSKI, C., ACHOURI, Y., BLOCH, W., HASSAN, B.A. and BLANPAIN, C. (2009). Epidermal progenitors give rise to Merkel cells during embryonic development and adult homeostasis. J Cell Biol 187: 91-100.

VAN STAADEN, M.J. and RÖMER, H. (1998). Evolutionary transition from stretch to hearing organs in ancient grasshoppers. Nature 394: 773-776.

VIELKIND, U., SEBZDA, M.K., GIBSON, I.R. and HARDY, M.H. (1995). Dynamics of Merkel cell patterns in developing hair follicles in the dorsal skin of mice, demonstrated by a monoclonal antibody to mouse keratin 8. Acta Anat 152: 93-109.

VOS, P., STARK, F. and PITTMAN, R.N. (1991). Merkel cells in vitro: Production of nerve growth factor and selective interactions with sensory neurons. Dev Biol 144: $281-300$

WALTHER, C. and GRUSS, P. (1991). Pax-6, a murine paired box gene, is expressed in the developing CNS. Development 113: 1435-1450.

WARREN, N. and PRICE, D.J. (1997). Roles of Pax-6 in murine diencephalic development. Development 124: 1573-1582.

WOO, S.H., STUMPFOVA, M., JENSEN, U.B., LUMPKIN, E.A. and OWENS, D.M.(2010). Identification of epidermal progenitors for the Merkel cell lineage. Development 137: 3965-3971.

WOODBURY,C.J.and KOERBER,H.R.(2007).Central and peripheral anatomy of slowly adapting type I low-threshold mechanoreceptors innervating trunk skin of neonatalmice. J Comp Neurol 505: 547-561.

ZHOU, Y., WU, X., TAN, F., SHI, Y., GLASS, T., LIU, T.J., WATHEN, K., HESS, K.R., GUMIN, J., LANG, F. and YUNG, W.K.A. (2005) PAX6 suppresses growth of human glioblastoma cells. J Neuro-Oncol 71: 223-229. 


\section{Further Related Reading, published previously in the Int. J. Dev. Biol.}

Dynamic expression of manganese superoxide dismutase during mouse embryonic organogenesis Jung-Min Yon, In-Jeoung Baek, Beom Jun Lee, Young Won Yun and Sang-Yoon Nam Int. J. Dev. Biol. (2011) 55: 327-334

Neuronal induction and regional identity by co-culture of adherent human embryonic stem cells with chicken notochords and somites

Hossein Salehi, Khadijeh Karbalaie, Shahnaz Razavi, Somaieh Tanhaee, Marziyh Nematollahi, Mohsen Sagha, Mohammad-Hossein Nasr-Esfahani and Hossein Baharvand Int. J. Dev. Biol. (2011) 55: 321-326

Early mammalian embryo: my love. An interview with Andrzej K. Tarkowski Marek Maleszewski and Andrzej K. Tarkowski Int. J. Dev. Biol. (2008) 52: 163-169

Interplay of Pax6 and SOX2 in lens development as a paradigm of genetic switch mechanisms for cell differentiation

Hisato Kondoh, Masanori Uchikawa and Yusuke Kamachi Int. J. Dev. Biol. (2004) 48: 819-827

Analysis of mouse eye development with chimeras and mosaics J. Martin Collinson, Robert E. Hill and John D. West Int. J. Dev. Biol. (2004) 48: 793-804

Expression pattern of PAX3 and PAX6 genes during human embryogenesis $\mathrm{J}$ Terzic and M Saraga-Babic

Int. J. Dev. Biol. (1999) 43: 501-508

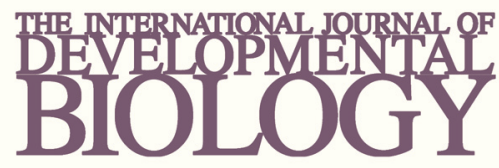

Volume 54 Nos. 6/7
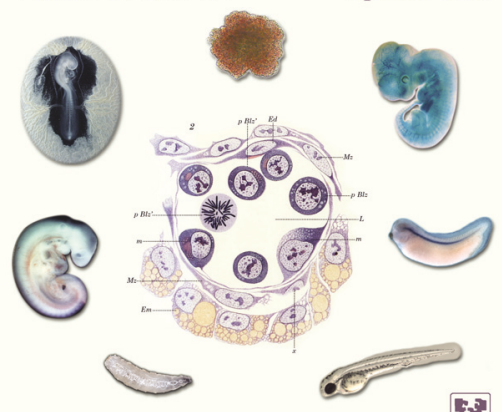

Developmental Hematopoiesis
5 yr ISI Impact Factor $(2010)=2.961$

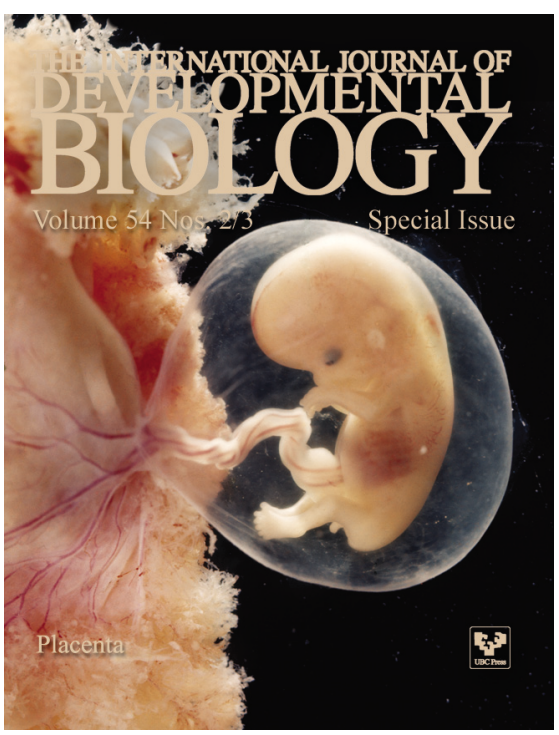

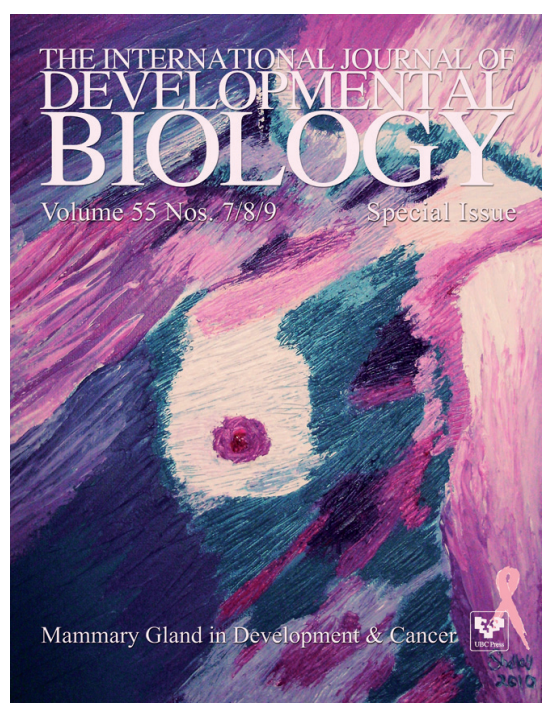

THE INTERNATIONAL JOURNAL OF

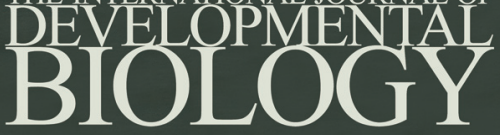
Volume 55 Nos. $4 / 5$

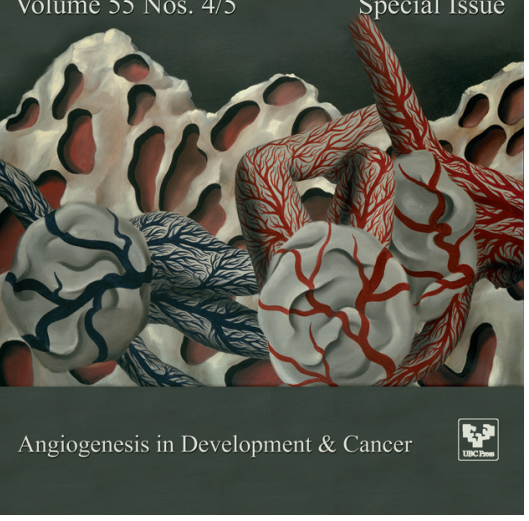

